\title{
HUBUNGAN PEMANFAATAN PERPUSTAKAAN DENGAN PRESTASI BELAJAR MAHASISWA SEMESTER IV PRODI D-III KEBIDANAN FAKULTAS ILMU KESEHATAN UNIVERSITAS MUHAMMADIYAH TANGERANG TAHUN AKADEMIK 2016/2017
}

\author{
Catur Erty Suksesty ${ }^{1}$, Yayah Huliatunisa ${ }^{3}$, Eneng Wiliana ${ }^{3}$, Sucita Nurwahyuningsih ${ }^{4}$ \\ Universitas Muhammadiyah Tangerang
}

\begin{abstract}
ABSTRAK
Prestasi belajar adalah hasil yang telah dicapai oleh seseorang setelah ia melakukan proses belajar, serta merupakan kecakapan atau hasil konkrit yang dapat dicapai pada saat atau periode tertentu, yang dalam hal ini mahasiswa dalam proses pembelajaran. Pembelajaran itu sendiri merupakan suatu sistem yang didalamnya terdapat berbagai komponen, antara lain tujuan, materi, metode, media, sumber belajar, evaluasi, peserta didik, lingkungan dan guru yang saling berhubungan dan ketergantungan satu sama lain serta berlangsung secara terencana dan sistemik.
\end{abstract}

Perpustakaan merupakan kawasan pemanfaatan dalam teknologi pendidikan yang membidangi tentang bagaimana secara teori dan praktek proses dan sumber-sumber belajar dimanfaatkan untuk kepentingan belajar. Perpustakaan sebagai salah satu sumber belajar merupakan sarana yang didalamnya memuat bahan-bahan belajar dan dapat digunakan sebagai acuan dalam mengelola materi perkuliahan, sehingga pemenuhan kebutuhan akan belajar dapat mencapai hasil yang optimal.

Penelitian ini bertujuan mengetahui adanya hubungan pemanfaatan perpustakaan dengan prestasi belajar mahasiswa, dengan menggunakan desain deskriptif analitik dengan pendekatan cross sectional, dan menjadikan seluruh mahasiswa semester IV Prodi D-III Kebidanan Fakultas llmu Kesehatan Universitas Muhammadiyah Tangerang TA. 2016/2017 yang berkunjung ke perpustakaan Fakultas Ilmu Kesehatam Universitas Muhammadiyah Tangerang sebagai populasi dengan menggunakan teknik purposive sampling dengan jumlah 51 mahasiswa, selanjutnya data yang diperoleh dalam penelitian ini diolah dengan menggunakan uji chi-square dengan derajat kemaknaan $(\alpha=0,05)$. Hasil penelitian menunjukkan ada hubungan antara pemanfaatan perpustakaan dengan kejadian prestasi belajar dengan nilai $(\mathrm{p}$ value $=0,030)$.

Saran dari hasil penelitian ini yakni tersedianya system layanan dalam proses pencarian sumber belajar di perpustakaan dengan menggunakan sistem layanan informasi perpustakaan mandiri yang dapat diakses secara langsung oleh mahasiswa.

Kata Kunci : Prestasi Belajar, Pemanfaatan Perpustakaan

\section{PENDAHULUAN}

Pesatnya perkembangan ilmu pengetahuan dan tekhnologi mendorong adanya sumber daya manusia yang berkualitas. Pendidikan-lah yang dianggap merupakan penyumbang utama serta berperan besar dalam membentuk pribadi manusia sehingga menciptakan sumber daya manusia yang berkualitas tersebut.

Pendidikan adalah usaha sadar dan terencana untuk mewujudkan suasana belajar dan proses pembelajaran agar peserta didik secara aktif mengembangkan potensi dirinya untuk memiliki kekuatan spiritual keagamaan, pengendalian diri, 
kepribadian, kecerdasan, akhlak mulia serta keterampilan yang diperlukan dirinya, masyarakat, bangsa dan negara. (UU No 20 tahun 2003, 2003:4). Salah satu komponen dalam sistem pendidikan adalah pembelajaran. Pembelajaran itu sendiri merupakan suatu sistem yang didalamnya terdapat berbagai komponen, antara lain tujuan, materi, metode, media, sumber belajar, evaluasi, peserta didik, lingkungan dan guru yang saling berhubungan dan ketergantungan satu sama lain serta berlangsung secara terencana dan sistemik. (Komsiyah, 2012)

Pendidikan Tinggi adalah jenjang tertinggi pada jalur pendidikan dengan tugas dan kewenangan untuk menyelenggarakan program pendidikan akademik dan profesional. Pendidikan akademik adalah program pendidikan yang diarahkan terutama pada pengembangan ilmu pengetahuan, teknologi dan atau seni. Sedangkan pendidikan profesional adalah program pendidikan yang diarahkan terutama pada kesiapan penerapan keahlian tertentu.

Universitas Muhammadiyah Tangerang yang berlokasi di Jl. Perintis Kemerdekaan I No. 33 Cikokol, Kota Tangerang, Provinsi Banten, merupakan sebuah Perguruan Tinggi yang didirikan di bawah naungan Majelis Pendidikan Tinggi Penelitian dan Pengembangan (DIKTILITBANG) Muhammadiyah dengan standar penerbitan SK Mendiknas RI Nomor 142/D/O/2010 sebagai ralat dari nomor $109 / \mathrm{D} / \mathrm{O} / 2009$ tentang pendirian Universitas Muhammadiyah Tangerang. Merupakan gabungan dari STIEM, STAIM dan STIKES Muhammadiyah. (Http://www.umt.ac.id)

Universitas Muhammadiyah Tangerang membuka beberapa Fakultas, antara lain: Fakultas Ekonomi (S.1 Akuntansi, S.1 Manajemen dan D.3 Akuntansi), Fakultas Agama Islam (S.1 PAI, S.1 MPS, S.1 Pendidikan Bahasa Arab), Fakultas Kesehatan (S.1 Keperawatan, D.III Kebidanan dan D.IV Bidan Pendidik), Fakultas Keguruan dan
Ilmu Pendidikan (S.1 PGSD, S.1 PGPAUD, S.1 Pend MTK, S.1 Pend B.Inggris dan S.1 Pend B. Indonesia), Fakultas Teknik (S.1 Teknik Informatika, Teknik Elektro, Teknik Mesin dan Teknik Industri), Fakultas Hukum (S.1 Ilmu Hukum) Fakultas Ilmu Sosial dan Ilmu Politik (S.1 Ilmu Pemerintahan dan S.1 Ilmu Komunikasi) dan Program Pascasarjana (Magister Manajemen dan Magister Studi Islam). (http://www.umt.ac.id)

Untuk mencapai tujuan yang telah digariskan dalam Tri Dharma Pendidikan Tinggi yaitu peningkatan mutu pendidikan dan pengajaran, penelitian dan pengabdian kepada masyarakat. Pendidikan Tinggi harus berusaha semaksimal mungkin untuk mewujudkan lingkungan kampus yang mendukung ke arah pencapaian tersebut. Salah satu diantaranya adalah pemanfaatan pendukung penggerak kurikulum yaitu perpustakaan.

Kata perpustakaan berasal dari kata pustaka, yang berarti: (1) kitab, buku-buku; (2) kitab primbon. Kemudian kata pustaka mendapat awalan per dan akhiran an, menjadi perpustakaan. Perpustakaan mengandung arti: (1) Suatu koleksi materi literer atau artistik, seperti buku-buku dan cetakan-cetakan; (2) Himpunan buku-buku dan bahan serupa lainnya yang dikelola untuk bacaan, kajian dan konsultasi. (3) Suatu tempat dimana buku-buku atau bahan literer dan artistik lainnya disimpan untuk digunakan, bukan untuk dijual. (4) Ruangan atau bangunan yang menjadi tempat himpunan buku-buku dan bahan serupa lainnya diorganisasikan dan diadministrasikan untuk bacaan, kajian, dan konsultasi.

Secara umum, tujuan perpustakaan perguruan tinggi adalah; (a) Memenuhi keperluan informasi masyarakat perguruan tinggi, lazimnya staf pengajar dan mahasiswa. Sering pula mencakup tenaga administrasi perguruan tinggi, (b) Menyediakan bahan pustaka rujukan (referens) pada semua tingkat akademis, 
artinya mulai dari mahasiswa tahun pertama hingga mahasiswa program pasca sarjana dan pengajar, (c) menyediakan ruangan belajar untuk pemakai perpustakaan, (d) menyediakan jasa peminjaman yang tepat guna bagi berbagai jenis pemakai, (e) menyediakan jasa informasi aktif yang tidak saja terbatas pada lingkungan perguruan tinggi tetapi juga lembaga industri lokal (Sulistyo Basuki, 2009)

Perpustakaan berfungsi sebagai pusat sistem belajar mengajar bagi civitas akademika perguruan tinggi yang bersangkutan sehingga menghasilkan lulusan yang bermutu tinggi, sebagai tempat terselenggaranya penelitian bagi civitas akademika perguruan tinggi sehingga ilmu pengetahuan dan teknologi dapat berkembang dengan baik, sebagai sarana untuk kerjasama dengan pihak-pihak luar perguruan tinggi dalam pengumpulan, pengolahan serta penyebarluasan informasi ilmu pengetahuan dan teknologi

Pemanfaatan perpustakaan oleh mahasiswa sangat erat kaitannya dengan proses perkuliahan yang diselenggarakan oleh Perguruan Tinggi. Hal ini karena pola pengajaran yang disebut sebagai keterbukaan informasi untuk memperoleh sebanyak-sebanyaknya ilmu pengetahuan hanya akan terlaksana jika mahasiswa dapat memanfaatkan perpustakaan. Dosen hanya memberikan kuliah-kuliah secara garis besarnya saja, sedangkan untuk detailnya mahasiswa diminta mengembangkan melalui buku-buku, termasuk buku-buku yang ada di perpustakaan, kemudian mata kuliah itu diseminarkan atau didiskusikan. Sistem seperti ini menjadikan mahasiswa harus memanfaatkan perpustakaan untuk mencari dan menelaah buku-buku yang ada di perpustakaan dalam proses belajarnya. (Noerhayati, 2011)

Fasilitas perpustakaan yang baik dan lengkap disertai dengan penciptaan suasana yang nyaman dapat menarik MINAT mahasiswa untuk mau mengunjungi perpustakaan, dengan demikian dapat membantu mahasiswa untuk belajar dan memperkaya wawasannya. Perpustakaan yang sudah dimanfaatkan dan yang belum dimanfaatkan dengan optimal dapat dilihat dari banyaknya jumlah pengunjung maupun banyaknya buku yang dibaca dan dipinjam.

Perpustakaan pada Fakultas Ilmu Kesehatan Universitas Muhammadiyah Tangerang menyediakan berbagai fasilitas dan layanan termasuk didalamnya bahan literatur, jurnal, majalah, dan hasil-hasil penelitian, dengan harapan dapat dimanfaatkan sepenuhnya serta dapat dijadikan sumber belajar penting dalam proses pembelajaran yang akan menunjang peningkatan prestasi mahasiswa.

Berdasarkan observasi pendahuluan, peneliti menemukan beberapa hal yang menjadi salah satu faktor di kalangan mahasiswa yang tidak memanfaatkan perpustakaan dalam proses belajarnya karena merasa bahwa bahan kuliah yang diberikan oleh dosen sudah mencukupi. Selain itu, kurangnya tugas pengembangan bahan kuliah dan tugas mandiri dari dosen menyebabkan mahasiswa tidak termotivasi untuk pergi berkunjung ke perpustakaan untuk menelaah dan mencari bahan kuliah, yang akhirnya berdampak pada tidak semua mahasiswa memiliki hasil studi dan kemampuan yang sama. Kebanyakan mahasiswa Fakultas Ilmu Kesehatan mempunyai kebiasaan membaca buku di perpustakaan pada saat membuat laporan dan skripsi, sehingga yang memanfaatkan perpustakaan Fakultas hanya mahasiswa tertentu. Hal ini dapat diketahui dengan rata-rata kunjungan ke perpustakaan 5 orang per hari dari 51 mahasiswa semester IV Prodi D-III Kebidanan Fakultas Ilmu Kesehatan Universitas Muhammadiyah Tangerang Tahun Akademik 2016/2017. Angka yang ditunjukkan berdasarkan observasi tersebut jelas menggambarkan bahwa perpustakaan sebagai pusat sumber belajar yang tersedia belum dapat sepenuhnya dimanfaatkan oleh mahasiswa.

Berdasarkan hal tersebut di atas, maka penelitian ini bertujuan untuk mengetahui 
hubungan antara Pemanfaatan Perpustakaan dan Prestasi Belajar Mahasiswa semester IV Prodi D-III Kebidanan Fakultas Ilmu Kesehatan Universitas Muhammadiyah Tangerang Tahun Akademik 2016/ 2017, dalam upaya menunjang tercapainya prestasi belajar yang maksimal.

\section{METODE PENELITIAN}

\section{Desain Penelitian}

Desain penelitian ini menggunakan metode deskriptif analitik dengan pendekatan cross sectional, dengan tujuan mengetahui adanya hubungan pemanfaatan perpustakaan dengan prestasi belajar mahasiswa, rentang waktu pelaksanaan pada Bulan Mei-Juni 2017, populasinya adalah seluruh mahasiswa Fakultas Ilmu Kesehatan-UMT yang datang/berkunjung ke perpustakaan FIKes-UMT. Teknik pengambilan sampel menggunakan tehnik purposive sampling yakni seluruh mahasiswa semester IV Prodi D-III Kebidanan FIKes-UMT yang berjumlah 51 Mahasiswa.

\section{Analisa Data}

Teknik analisa data dalam penelitian ini adalah menggunakan analisis univariat dan bivariat. Analisa univariat dilakukan terhadap setiap variabel yang diteliti, selanjutnya data yang telah diolah dari kuesioner dimasukkan ke dalam tabel distribusi frekuensi, kemudian di persentase ke tiap-tiap kategori, sedangkan analisa bivariat dilakukan terhadap dua variabel yang di duga berhubungan atau berkolerasi. Uji statistik yang akan digunakan pada penelitian ini adalah chi square yang diolah menggunakan program komputerisasi.

\section{Persyaratan Uji chi Square:}

1. Bila tabel lebih dari $2 \times 2$ menggunakan person chi square tanpa korelasi (uncorrected).
2. Bila tabelnya $2 \times 2$ dan tidak ada nilai $\mathrm{E}<5$, menggunakan Countinity Corection.

3. Bila tabelnya $2 \times 2$ ada nilai $\mathrm{E}<5$ maka menggunakan Fisher Exact.

Untuk tabel $\alpha$ (alpha) tergantung dari tujuan dan kondisi penelitian. Untuk bidang kesehatan masyarakat biasanya digunakan nilai $\alpha$ (alpha) sebesar 5\%. Oleh karena itu, peneliti dalam penelitian yang akan dilakukan ini menggunakan level of significance $(\alpha=$ alpha) sebesar $5 \%$ $(0,005)$. Sehingga analisis penelitian ini dapat diambil kesimpulan sebagai berikut:

1. Bila $p$ value $<\alpha$, berarti ada hubungan bermakna (signifikan) antara variabel dependent dan variabel independent.

2. Bila $\mathrm{p}$ value $>\alpha$, berarti tidak ada hubungan bermakna (signifikan) antara variabel dependent dan variabel independent.

\section{HASIL PENELITIAN}

\section{Analisa Univariat}

Distribusi Frekuensi Kejadian Prestasi Belajar terhadap Pemanfaatan Perpustakaan Semester IV Prodi D-III Kebidanan Fakultas Ilmu Kesehatan Universitas Muhammadiyah Tangerang Tahun Akademik 2016/2017

\begin{tabular}{lcc}
\hline $\begin{array}{l}\text { Prestasi } \\
\text { Belajar }\end{array}$ & N & $(\boldsymbol{\%})$ \\
\hline Baik & 34 & 66,7 \\
\hline Kurang & 17 & 33,3 \\
\hline Total & $\mathbf{5 1}$ & $\mathbf{1 0 0}$ \\
\hline
\end{tabular}

Dari 51 mahasiswa semester IV Prodi D-III kebidanan yang baik dalam prestasi belajar $66,7 \%$. Sedangkan yang kurang dalam prestasi belajar sebesar 33,3\%.

Distribusi Frekuensi Kejadian Pemanfaatan Perpustakaan Semester IV 
Prodi D-III Kebidanan Fakultas Ilmu Kesehatan Universitas Muhammadiyah Tangerang Tahun Akademik 2016/2017

\begin{tabular}{lcc}
\hline $\begin{array}{l}\text { Pemanfaatan } \\
\text { Perpustakaan }\end{array}$ & N & $(\boldsymbol{\%})$ \\
\hline Baik & 33 & 64,7 \\
\hline Kurang & 18 & 35,3 \\
\hline Total & $\mathbf{5 1}$ & $\mathbf{1 0 0}$ \\
\hline
\end{tabular}

Dari 51 mahasiswa semester IV Prodi D-III kebidanan yang baik dalam pemanfaatan perpustakaan $64,7 \%$. Sedangkan yang kurang dalam pemanfaatan perpustakaan sebesar 35,3\%.

\section{ANALISA BIVARIAT}

a. Hubungan antara Pemanfaatan Perpustakaan dengan Prestasi Belajar Mahasiswa Semester IV Prodi D-III Kebidanan Fakultas Ilmu Kesehatan Universitas Muhammadiyah Tangerang Tahun Akademik 2016/ 2017

Hubungan Antara Pemanfaatan Perpustakaan terhadap Prestasi Belajar Semester IV Prodi D-III Kebidanan Fakultas Ilmu Kesehatan Universitas Muhammadiyah Tangerang Tahun 2016/2017

\begin{tabular}{|c|c|c|c|c|}
\hline \multirow{3}{*}{$\begin{array}{l}\text { Pemanfaa } \\
\text { tan } \\
\text { Perpusta } \\
\text { kaan }\end{array}$} & \multicolumn{2}{|c|}{ Prestasi Belajar } & \multirow[t]{2}{*}{ Total } & \multirow{2}{*}{$\begin{array}{l}P \\
\text { Value }\end{array}$} \\
\hline & Baik & Kurang & & \\
\hline & $\%$ & $\mathbf{n}$ & $\%$ & $\mathbf{0 , 0 3 0}$ \\
\hline
\end{tabular}

$\begin{array}{lcccccc}\text { Baik } & 26 & 78,8 & 7 & 21,2 & 33 & 100 \\ \text { Kurang } & 8 & 44,4 & 10 & 55,6 & 18 & 100 \\ \text { Jumlah } & \mathbf{3 4} & \mathbf{6 6 , 7} & \mathbf{1 7} & \mathbf{3 3 , 3} & \mathbf{5 1} & \mathbf{1 0 0}\end{array}$

Berdasarkan tabel 4.3 diketahui bahwa dari 34 mahasiswa yang pemanfaatan baik terhadap prestasi belajar yaitu sebanyak 26 orang $(78,8 \%)$ dan dari 17 yang pemanfaatan perpustakaan kurang terhadap prestasi belajar sebanyak 8 orang $(44,4 \%)$.

Dari hasil analisis bivariat dengan menggunakan uji chi-square diperoleh nilai $p$ value $=0,030$ dimana nilai $p$ value lebih kecil dari pada $\alpha(0,05)$. Maka ada hubungan yang bermakna antara pemanfaatan perpustakaan terhadap prestasi belajar pada mahasiswa semester IV Prodi D-III kebidanan Fakultas Ilmu Kesehatan Universitas Muhammadiyah Tangerang Tahun Akademik 2016/ 2017.

\section{PEMBAHASAN}

\section{ANALISA UNIVARIAT}

\section{a. Distribusi Frekuensi Pemanfaatan Perpustakaan Berdasarkan Prestasi Belajar}

Dari hasil penelitian didapatkan mahasiswa yang prestasi baik sebesar $64,7 \%$. Hal ini sesuai dengan teori yang dikemukakan Noerhayati, 2011, perpustakaan Perguruan Tinggi adalah untuk mendukung, memperlancar serta mempertinggi kualitas pelaksanaan program kegiatan perguruan tinggi melalui pelayanan informasi, pengelolaan informasi, pemanfaatan informasi. Fungsi perpustakaan tersebut, antara lain adalah pendidikan dan pembelajaran, informasi, penelitian, rekreasi, dan preservasi. Fungsifungsi itu dilaksanakan dalam rangka pencapaian tujuan perpustakaan. Sementara tujuan yang akan dicapai atas peran, tugas dan fungsi perpustakaan secara singkat adalah terjadinya transformasi dan transfer ilmu pengetahuan dari sumbernya di perpustakaan kepada mahasiswa. Hasilnya adalah terjadinya perubahan, baik dalam hal kemampuan, sikap, maupun keterampilan. Pendek kata, manusiamanusia yang dengan tekun belajar dan membaca di perpustakaan pada suatu ketika diharapkan dapat menjadi manusiamanusia yang menguasai informasi, pengetahuan, wawasan, berperilaku arif dan bijaksana, berpandangan jauh ke 
depan, sehingga dalam mengambil keputusan lebih tepat. Karena segala sesuatunya telah dipikirkan dengan matang didasarkan pada pertimbangan analisis ilmiah (Wiji Suwarno, 2009). Sehingga dengan mahasiswa sering mempergunakan perpustakaan maka akan memperbanyak ilmu dan wawasan yang akan diperoleh sehingga akan berdampak kepada mahasiswa yang berprestasi.

\section{ANALISA BIVARIAT}

\section{b. Hubungan Perpustakaaan dengan Prestasi Belajar}

Dari hasil uji chi-square menunjukan $p$-value $=0,030$ lebih kecil dari pada $\alpha$ $(0,05)$. Hal ini berarti ada hubungan yang bermakna antara pemanfaatan perpustakaan dengan prestasi belajar mahasiswa semester IV Prodi D-III Kebidanan Fakultas Ilmu Kesehatan Universitas Muhammadiyah Tangerang Tahun Akademik 2016/2017.

Hal ini didukung oleh teori Noerhayati, 2011, dimana Dosen hanya memberikan kuliah-kuliah secara garis besarnya saja, sedangkan untuk detailnya mahasiswa diminta mengembangkan melalui bukubuku, termasuk buku-buku yang ada di perpustakaan, kemudian mata kuliah itu diseminarkan atau didiskusikan. Sistem seperti ini menjadikan mahasiswa harus memanfaatkan perpustakaan untuk mencari dan menelaah buku-buku yang ada di perpustakaan dalam proses belajarnya. Selain itu, dalam menyiapkan tugas yang diberikan oleh dosen berupa tugas pengembangan, mahasiswa juga tidak terlepas dari pemanfaatan perpustakaan. Informasi yang terkandung dalam bahan pustaka terdapat di perpustakaan yang menyediakan bahan untuk mengembangkan pikiran dan memperluas wawasan mahasiswa yang dapat mereka tuangkan dalam menyiapkan tugas tersebut.

Perpustakaan sebagai gudang ilmu menyediakan berbagai macam bahan sumber informasi dan fasilitas yang tidak terbatas jumlahnya dalam bentuk buku, jurnal, majalah, dan sebagainya untuk kemudahan belajar mahasiswa. Koleksi buku dan bahan pustaka tersebut mengandung berbagai informasi yang diperlukan oleh mahasiswa dalam proses belajarnya seperti bahan untuk menyiapkan tugas, menambah wawasan, melengkapi materi dari dosen dan persiapan ujian. (Wiji Suwarno,2010).

Penelitian ini sejalan dengan Dwi Teguh Laksono tentang Pemanfaatan Perpustakaan Sekolah Sebagai Sarana Belajar Siswa Di SMK Muhammadiyah 1 Salam, Berdasarkan analisis data penelitian tersebut dapat disimpulkan bahwa pemanfaatan perpustakaan sekolah di SMK Muhammadiyah 1 Salam sudah cukup baik. Secara umum jenis koleksi yang disukai siswa sudah baik, dengan skor rata-rata koleksi sebesar 15,09; frekuensi kunjungan sebesar 48,9; dan jenis koleksi yang disukai sebesar 25,65. Bahan bacaan atau referensi yang digunakan siswa masih sangat terbatas.

\section{KESIMPULAN}

Setelah dilakukan penelitian tentang "Hubungan Pemanfaatan Perpustakaan terhadap Prestasi Belajar Semester IV Prodi D-III Kebidanan Fakultas Ilmu Kesehatan Universitas Muhammadiyah Tangerang Tahun Akademik 2016/2017" pada bulan Mei-Juni tahun 2017 maka peneliti dapat mengambil kesimpulan sebagai berikut:

1. Distribusi frekuensi kejadian prestasi belajar Mahasiswa Semester IV Prodi D-III Kebidanan Fakultas Ilmu Kesehatan Universitas Muhammadiyah Tangerang yaitu dengan kategori prestasi belajar baik sebanyak 34 (66,7\%).

2. Distribusi frekuensi responden pemanfaatan perpustakaan dengan kejadian prestasi belajar Mahasiswa Semester IV Prodi D-III Kebidanan Fakultas Ilmu Kesehatan Universitas Muhammadiyah yaitu yang 
pemanfaataan perpustakaan dengan baik sebanyak 33 (64,7\%).

3. Dari Hasil statistik didapatkan ada hubungan antara pemanfaatan perpustakaan dengan kejadian prestasi belajar

\section{SARAN}

\section{Bagi Mahasiswa Prodi D3 kebidanan}

Diharapkan Mahasiswa semester IV Prodi D-III Kebidanan Fakultas Ilmu Kesehatan Universitas Muhammadiyah Tangerang hendaknya menjadikan perpustakaan sebagai salah satu sarana belajar dan sarana untuk mencari referensi materi perkuliahan.

\section{Untuk Institusi}

Agar lebih memperhatikan mahasiswa dalam mencari buku dengan menggunakan sistem layanan informasi perpustakaan sehingga mahasiswa dapat mengakses sendiri.

\section{DAFTAR PUSTAKA}

Basuki, Sulistyo, Pengantar Ilmu Perpustakaan, Jakarta: PT Gramedia Pustaka

Utama, 2009

Dalyono, Psikologi Pendidikan, Jakarta: Rineka Cipta, 2007.

Darmono, 2007. Perpustakaan Sekolah : Pendekatan Aspek Manajemen Dan Tata Kerja. Jakarta : Grasindo

Lasa, 2007. Manajemen Perpustakaan Sekolah. Yogyakarta : Pinus

Notoatmodjo, S. 2012. Metodologi Penelitian Kesehatan. Jakarta : PT Rineka Cipta

Papalia, Diane \& Feldman, RD, 2008. Human Development. Jakarta : Kencana
Rahayuningsih, Pengelolaan Perpustakaan, Yogyakarta: Graha Ilmu, 2007

Santrock, John W, 2002. Life Span Development. Jakarta : Erlangga

Siswoyo, Dwi. 2007. Ilmu Pendidikan. Yogyakarta : UNY Press

Sudjana, Nana, Dasar-dasar Proses Belajar Mengajar, Jakarta: Sinar Baru Algensindo, 2009.

Sugiyono, 2009. Metode Penelitian kuantitatif, kualitatif, dan $R \& D$. Bandung : Alfabeta

Suryabrata, Sumadi, Metodologi Penelitian, Jakarta: CV. Rajawali Pers, 2009

Sutarno NS, 2006. Perpustakaan Dan Masyarakat. Jakarta : Sagung Seto

Suwarno, Wiji, Psikologi Perpustakaan, Jakarta: Sagung Seto, 2009

Yusuf, Syamsu, 2012. Psikologi Perkembangan Anak Dan Remaja. Bandung : Remaja Rosdakarya 